\section{In Memory of Kerry R. Kelts, 1947-2001}

Kerry Kelts, professor in the department of Geology and Geophysics, and director of the Limnological Research Center (LRC), University of Minnesota, died on February 8, 2001, after a long battle with Hodgkins Disease.

Kerry received his undergraduate degree in Geophysics at the University of California-Riverside in 1967 and his PhD from the Swiss Federal Institute for Technology (ETH), Zürich, Switzerland, in 1978. From 1978 to 1980 he was the Deep-Sea Drilling Project Staff Scientist for Leg 64 at the Scripps Institute for Oceanography, La Jolla, California, before joining the Geological Institute at the ETH, Zürich, as lecturer, from 1980 to 1985. From 1985 to 1990 he was Head of the Geology Group of the Swiss Federal Institute forWater Resources (EAWAG). From 1988 to 1990 he served as the first director of the newly formed Swiss National Climate Program (Proclim) and was instrumental, jointly with Prof. Dr. H. Oeschger, in the development of the IGBP-PAGES program. In 1990 he answered a call to lead the LRC at the University of Minnesota.

Kerry edited and co-edited two books and nine special journal issues and monographs, including "Lacustrine Petroleum Source Rocks" (1988), “The Phanerozoic Record of Lacustrine Basins and their Environmental Signals" (1989), "Comparative Lacustrine Sedimentation in China" (1990), and "Global Geological Record of Lacustrine Basins" (1994). He authored and co-authored over 100 papers. His research interests focused on reconstructing paleoclimate history from isotopic, geochemical and sedimentological signatures in lake deposits from the Americas, Africa, Near East and China. As a participant and later staff scientist of deep-sea drilling projects he brought to the lake community oceanographic expertise in terms of technological advances for field operations and what he called the "DSDP way" of processing cores. The core processing and archiving facility that he created at the LRC with NSF support, and which is available to our whole community, is the best such facility in the United States. Kerry was the main driving force behind the funding, building, and testing of the versatile and powerful Global Lake Drilling System capable of handling up to 800 meters of drill string (GLAD800). He was on the deck of the Glomar Challenger in 1978 on DSDP Leg 64 when the first hydraulic piston core was collected in the ocean, and he was on the deck of the GLAD800 barge last summer when the first hydraulic piston core was collected from Great Salt Lake, a dream that took 22 years to realize. In his honor, the GLAD800 drill rig has been named the $R / V$ Kerry Kelts. In the years to come, the $R / V$ Kerry Kelts will core large lakes all over the world, a fitting tribute.

Kerry's enthusiasm for his research was infectious, inspiring students and colleagues. His holistic approach to the study of lakes and his vision were the catalysts for interdisciplinary and international collaboration. He was the co-founder of the International Decade for East African Lakes (IDEAL), the founder and first president of the International Association of Limnogeology, and coordinator of Project 219 (Comparative Lacustrine Sedimentology in Space andTime) and Project 324 (Global Paleoenvironmental Archives in Lacustrine Systems: GLOPALS) of the International Geological Correlation Program (IGCP).

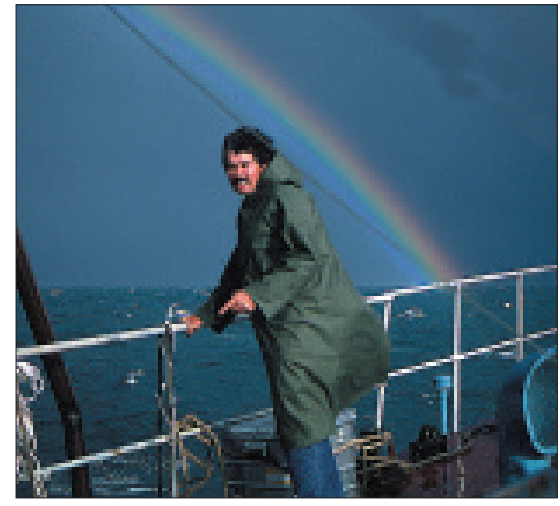

All of us who crossed paths with Kerry learned from his passionate pursuit of science and profited from his generosity, scientifically and personally. He represented the perfect blend of the best characteristics of the New and Old World science. His New World enthusiastic "can do" attitude coupled with his personal charm and persuasiveness was the stimulus for many of the ongoing international global change research initiatives. From the Old World he projected the technological precision, quality and dedication, which gave all his projects perfection and a touch of class. We will all miss him.

\section{Vera Markgraf}

University of Colorado, Boulder, USA markgraf@spot.colorado.edu

\section{Walter E. Dean}

U.S. Geological Survey, Denver, USA dean@usgs.gov

Tom D. Johnson

Large Lakes Observatory,

University of Minnesota, Duluth, USA tcj@d.umn.edu

\section{Steve Colman}

U.S. Geological Survey, Woods Hole, USA scolman@usgs.gov 